\title{
Chemical Constituents and Antibacterial Activity of Essential Oils of Needles of Pinus Sylvestris (Scots Pine) from South West Nigeria
}

Kehinde A. Oyewole ( $\nabla$ kehinde.fayemiwo@uniosun.edu.ng )

Osun State University https://orcid.org/0000-0002-5097-0844

Omotayo 0. Oyedara

Osun State University

Shola H. Awojide

Osun State University

Mary 0. Olawade

Osun State University

Charles 0. Adetunji

Edo University lyamho

\section{Research Article}

Keywords: antibacterial, essential oil composition, gas chromatography/mass spectrophotometry, Nigeria, Pinus sylvestris

Posted Date: June 22nd, 2021

DOl: https://doi.org/10.21203/rs.3.rs-635195/v1

License: (c) (i) This work is licensed under a Creative Commons Attribution 4.0 International License. Read Full License 


\section{Abstract}

Pinus sylvestris (Scots pine) is a coniferous plant that possesses different biological properties such as antiseptic, antioxidant, antifungal, and anti-inflammatory. This study investigated the chemical constituents and in vitro antibacterial activities of essential oil (EO) of Pinus sy/vestris (Scots pine) against thirteen bacterial species using Gas chromatography/mass spectrophotometry (GC/MS) and standard agar well diffusion assay. The EO exhibited excellent antibacterial activity inhibiting all the bacterial isolates tested with the diameter zone of inhibitions $(Z i)$ ranging from 8-24 mm. The minimum inhibitory concentration (MIC) and the minimum bactericidal concentration (MBC) ranged between $0.025 \mathrm{mg} / \mathrm{ml}$ and $25.000 \mathrm{mg} / \mathrm{ml}$. The highest antibacterial activity was recorded against Micrococcus luteus NCIB 196 and Klebsiella pneumonia NCIB 418 ( $Z i=24 \mathrm{~mm})$, while the lowest activity was recorded against Proteus vulgaris $(Z i=8 \mathrm{~mm})$. The GC/MS analysis revealed the presence of 30 chemical compounds, of which seven possess antibacterial properties. These include three oxygenated monoterpenes (a-terpineol, borneol, and fenchol), two sesquiterpenes (caryophyllene and $\delta$-cadinene), one saturated fatty acid (palmitic acid) and monounsaturated fatty acid (oleic acids). Therefore, the results suggest the potential of $P$. sylvestris as an antimicrobial agent for incorporation in the treatment of pathogens.

\section{Introduction}

The application of antibiotics is one of the ways to control pathogenic and food spoilage bacteria that can have negative impacts on humans. However, these antibiotics are gradually failing due to several factors which include, the misuse and overuse of antibiotics without prescription for self-medication, usage of inferior antibiotics, uncontrolled application of antibiotics in animal husbandry and veterinary medicine, and dwindling rate of novel antibiotics discovery [1, 2]. These factors are the major forces enhancing the development of multidrug resistance among pathogens, which is now a major global challenge both in clinical and community settings. As a survival strategy, these multidrug-resistant bacteria develop different mechanisms of resistance to antibiotics, hence making infection treatment difficult and expensive [3]. Another consequence of the global antimicrobial resistance menace is the gradual shift from orthodox medicine to herbal therapy $[4,5]$ in an attempt to search for novel compounds that can serve as a better alternative to antibiotics.

Plants are a repository of several compounds that have useful applications in medicine and drug-making. For instance, morphine, which is the first natural product used for therapeutic purpose was isolated from opium (Papaver somniferum). Artemisinin from Artemisia annua, Paclitaxel from Taxus brevifolia, and Silymarin from Silybum marianum among others are some of the natural products that have been developed and sold as drugs [6, 7]. Pinus koraiensis pinecone essential oil has been shown to be effective in the production of anti-tumor drugs for gastric cancer [8]. Thus, essential oils (EOs) from several plants, including coniferous plants, have antimicrobial properties [8-12] suggesting their use as alternatives to conventional synthetic antibiotics. 
Furthermore, these EOs have a low level of toxicity, side effects, and chemical diversity in terms of activity compared to synthetic chemicals $[9,13-15]$, hence making them suitable for use as medicinal ingredients [16-19]. EOs also have potential to be developed into natural antioxidant in food systems, bio-control of stored product pest and fungi growth inhibitor [20, 21]. Despite their therapeutic applications, the usage of some EOs has been reported to cause side effects such as poisoning, dermatological, and neurological toxicity [10].

Pinus sy/vestris (Scots pine) belongs to the family Pinaceae, originated from Eurasia and mostly found in Northern and Eastern Europe. The genus Pinus is the most common coniferous plant with about 250 species distributed worldwide [22, 23]. The tree is about 25 to $40 \mathrm{~m}$ tall with evergreen, fragrant blue-green needle-like leaves of about 3 to $5 \mathrm{~cm}$ arranged alternately or spirally [24]. P. sy/vestris is the most diverse of any pine species worldwide with a wide array of applications [24]. The tree is an ornamental plant with environmental value in erosion control, and as a raw material in paper-making industries [25]. P. sy/vestris oil has wide arrays of medical applications due to its anti-parasitic, anti-viral, anti-allergenic, antispasmodic, anti-hyperglycemic, anti-inflammatory, and expectorant properties [26]. Moreover, the terpenic oil of $P$. sy/vestris is useful in pharmaceutical, chemical, cosmetic, perfume industries, even as food additives and preservatives [26]. The insecticidal and larvicidal properties of $P$. sy/vestris oil have also been reported [27].

In Nigeria, Sonibare and Olakunle reported the chemical composition and antibacterial properties of essential oil (EO) from needles of another species of Pinus, P. caribe (Caribbean pine) [22]. However, to the best of our knowledge, this report is the first to investigate the antibacterial properties of Pinus sylvestris (Scots pine) in Nigeria, and this current study, therefore, investigated the chemical constituents and antibacterial activity of EO of $P$. sylvestris needles obtained from Ibadan, South Western part of Nigeria.

\section{Materials And Methods \\ Plant collection}

In the month of May [28], the needles of $P$. sy/vestris were obtained near the Awolowo Hall at the University of Ibadan, South-Western Nigeria (Latitude: 7.45, Longitude: 3.90 ), and were identified in the herbarium of the Department of Botany, Obafemi Awolowo University, Ile-Ife, South-Western Nigeria. A voucher of herbarium specimen (IFE-17939) was deposited at the herbarium of Department of Botany, Obafemi Awolowo University, Ile-Ife, South-Western Nigeria.

\section{Extraction of EO from P. sylvestris needles}

Sixty millilitres of distilled water were added to grounded needles of $P$. sylvestris in a round bottom flask. EO was extracted from the needles in Clevenger's apparatus using the hydro-distillation method under optimal operating conditions [29]. The distillation process was done until a clear distillate was obtained. 
The distillates of EO were then dried over anhydrous sodium sulphate (CAS No. 7757-82-6) to remove impurities and water present in the distillates. Then, it was filtered and preserved at $4^{\circ} \mathrm{C}$ for further analysis.

\section{Chemical analysis of EO of P. sylvestris needles}

The Gas Chromatography/Mass Spectroscopy (GC/MS) technique was used to determine the chemical constituents of the EO obtained from the hydro-distillation of the needles. The GC/MS was done using HP 8060 Series II Gas chromatograph equipped with a flame ionization defector and HP-5MS (30 m x 0.25 $\mathrm{mm} \times 0.25 \mu \mathrm{m}$ ) capillary column; coupled to VG Platform II Mass spectrometer to carry out mass spectrometry analysis. The temperature of the source was maintained at $180^{\circ} \mathrm{C}$ at $300 \mathrm{~V}$. lon source pressure and MS detector were held at $9.4 \times 10^{-6}$ and $9.4 \times 10^{-6} \mathrm{mbar}$, respectively. The scan cycle of the MS was $1.5 \mathrm{sec}$ (scan duration of $1 \mathrm{~s}$ and inter-scan delay of $0.5 \mathrm{~s}$ ). Mass and scan range was set at $\mathrm{m} / \mathrm{z}$ 1-1400 and 38-650, respectively, and the instrument was calibrated using heptacosafluorotributyl amine $\left(\mathrm{C}_{12} \mathrm{~F}_{27} \mathrm{~N}\right)$ (CAS Number: 93792-84-8). The GC/MS column temperature was programmed as for GC, but the film thickness of GC/MS was $0.5 \mu \mathrm{m}$. The sample of $1 \mu \mathrm{l}$ was injected with a slip ratio of 1:10. All $\mathrm{GC} / \mathrm{MS}$ analyses were made in the splitless mode, with helium gas as the carrier.

The chemical constituents of the EO were identified and named by comparing the retention indices. The identified constituents were further confirmed by comparing the obtained mass spectra from the GC/MS analysis with the reference Library compound spectra in the database of the National Institute of Standard and Technology (NIST), and published spectra [30].

\section{Bacterial Isolates}

All the thirteen bacterial isolates used in this study were culture collections obtained from $\operatorname{Dr} \mathrm{D}$. A. Akinpelu of the Department of Microbiology, Obafemi Awolowo University, lle-lfe, Osun State, Nigeria. These include four bacterial isolates locally isolated from environmental samples (Corynebacterium pyogenes, Bacillus anthracis, Bacillus polymyxa, and Proteus vulgaris), and nine typed cultures including Bacillus cereus (NCIB 6349], Staphylococcus aureus (NCIB 8588), Bacillus stearothermophilus (NCIB 8222), Bacillus subtilis (NCIB 3610), Enterococcus faecalis (NCIB 775), Micrococcus luteus (NCIB 196), Escherichia coli (NCIB 86), Klebsiella pneumoniae (NCIB 418), and Pseudomonas fluorescens (NCIB 3756). The stock bacterial isolates were revived by culturing in nutrient broth and agar, and incubated at $37^{\circ} \mathrm{C}$ overnight, to observe bacterial growth.

\section{Determination of antibacterial activities of EO of P. sylvestris needles}

The EO of the $P$. sylvestris needles was screened for antibacterial activities using the agar well diffusion method, as described by Akinpelu et al. [31]. Bacterial isolates were cultured in nutrient broth for $18 \mathrm{~h}$ before standardization to $10^{6} \mathrm{CFU} \mathrm{mL}^{-1}$, an equivalent of $0.5 \mathrm{MacFarland}$ standard was done. A loopful of the standardized bacterial culture was aseptically inoculated into $20 \mathrm{~mL}$ of molten Mueller Hington 
agar (MHA) prepared in a McCartney bottle and already cooled to $45^{\circ} \mathrm{C}$. The inoculated MHA was mixed thoroughly, poured into a sterile Petri dish, and allowed to set. Sterile cork borer was used to bore two wells of $6 \mathrm{~mm}$ in diameter into the inoculated MHA, and $50 \mu \mathrm{L}$ of undiluted oil sample was dispensed into one of the wells. Streptomycin $\left(1 \mathrm{mg} \mathrm{mL}^{-1}\right)$ was dispensed into the second well to serve as a standard positive control. The inoculated petri dish was left on the bench at room temperature for $1 \mathrm{~h}$ to allow the diffusion of the oil into the medium and then incubated at $37^{\circ} \mathrm{C}$ for $24 \mathrm{~h}$. After incubation, the diameter zones of inhibition $(Z I)$ was measured using a ruler and recorded in millimetres $(\mathrm{mm})$.

Determination of Minimum Inhibitory Concentration (MIC) and Minimum bactericidal concentration (MBC) of EO of P. sylvestris needles

The MIC of the EO was determined against tested bacterial isolates using the agar dilution method, as described by Akinpelu et al. [31]. The EO was diluted serially in two-fold to obtain the following concentrations: $25.0,12.5,6.25,3.125,1.56,0.78,0.39,0.195,0.098,0.049$ and $0.025 \mathrm{mg} \mathrm{mL}^{-1}$. Then 2 $\mathrm{mL}$ aliquot of the different concentrations of the EO were added to $18 \mathrm{~mL}$ of molten sterile nutrient agar using a sterile pipette. The molten nutrient agar containing the different dilutions of EO was poured into a sterile petri dish and allowed to set. An $18 \mathrm{~h}$ old bacterial culture already standardized using the 0.5 MacFarland standard was streaked on the dried surface of the set nutrient agar plate using a sterile loop. The plates were incubated at $37^{\circ} \mathrm{C}$ for $24 \mathrm{~h}$ and observed for the presence or absence of bacterial growth. The MIC was taken as the lowest concentration at which no growth of the tested bacterial isolates occurred, while the MBC was taken as the next higher concentration to the MIC where no bacterial growth was observed.

\section{Data analysis}

Descriptive statistics were used with data analysis and graphs made using GraphPad Prism 7.0. (GraphPad Software, USA). All the experiments were done in triplicates, and data were expressed as arithmetic mean \pm SD (standard deviation).

\section{Result}

\section{GC/MS Analysis of EOs of P. sylvestris}

As reported in our earlier publication [27], thirty chemical constituents representing $90.50 \%$ of the oil were identified from the GC/MS analysis of EO of $P$. sylvestris needles. Seven of the identified chemical constituents are known antibacterial agents (Table 1). These include 3-Cyclohexene-1-methanol, a,a,4trimethyl- i.e. a-terpineol (27.17\%), borneol (6.72 \%), Bicyclo[2.2.1] heptan-2-ol,1,3,3-trimethyl i.e. fenchol (3.52 and $1.74 \%$ obtained at a retention time of 3.728 and 3.573 mins respectively), n-Hexadecanoic acid i.e. palmitic acid ( $1.32 \%)$, caryophyllene (1.30 and $0.16 \%$ obtained at a retention time of 8.70 and 9.301 mins respectively), oleic acid (0.57 \%), and naphthalene, 1,2,3,4,4a,5,6,8a-octahydro-7-methyl-4-methylene1-(1-m ethylethyl)-, (1.alpha, 4a.alpha, 8a.alpha.) i.e. $\delta$-cadinene (0.23\%). 


\section{Antibacterial Activity}

The study EO of $P$. sylvestris needles inhibited the growth of all the tested bacterial isolates with varied $Z i$ ranging between 8 and $24 \mathrm{~mm}$ (Fig. 1). The highest antibacterial activity was observed against Klebsiella pneumoniae (NCIB 418) and Micrococcus luteus [NCIB 196], while the lowest activity was observed against Pseudomonas fluorescens (NCIB 3756). The Zi observed for streptomycin, the standard antibiotic used as a control in this study ranged between 10 and $25 \mathrm{~mm}$. However, streptomycin did not inhibit the growth of Escherichia coli (NCIB 86) and Corynebacterium pyogenes.

\section{Minimum Inhibitory Concentration (MIC) and Minimum bactericidal concentration (MBC)}

The MIC and MBC results of EO of $P$. sylvestris were presented in Fig. 2. The EO of $P$. sy/vestris needles inhibited the growth of E. coli (NCIB 86), E. faecalis (NCIB 775), K. pneumoniae (NCIB 418), M. luteus (NCIB 196), P. fluorescens (NCIB 3756) and S. aureus (NCIB 8588) at a minimum concentration of 0.39 $\mathrm{mg} \mathrm{mL}^{-1}$ and $\mathrm{MBC}$ of $0.780 \mathrm{mg} \mathrm{mL}^{-1}$. Moreover, it was discovered that the lowest concentration value of $0.78 \mathrm{mg} \mathrm{mL}^{-1}$ derived from P. sylvestris EO was required to inhibit the growth of $B$. anthracis, $B$. cereus (NCIB 6349), and $B$. polymyxa respectively while the $\mathrm{MBC}$ of $1.56 \mathrm{mg} \mathrm{mL}^{-1}$ was established to be the minimum value that could prevent the growth of $B$. anthracis, B. cereus (NCIB 6349), and B. polymyxa respectively. The MIC for $C$. pyogenes, $B$. stearothermophilus (NCIB 8222), and B. subtilis (NCIB 3610) was $1.56 \mathrm{mg} \mathrm{mL}^{-1}$ while the $\mathrm{MBC}$ was $3.125 \mathrm{mg} \mathrm{mL}^{-1}$. The minimum concentration of EO that will kill Proteus vulgaris was $>25 \mathrm{mg} \mathrm{mL}^{-1}$, while the MIC was $25 \mathrm{mg} \mathrm{mL}^{-1}$.

\section{Discussion}

The EO from $P$. sylvestris needles obtained by hydro-distillation exhibited excellent broad-spectrum in vitro antibacterial activities against all bacterial isolates tested with the value of $Z i$ that ranged from 8 to 24 $\mathrm{mm}$. The EO compared favourably with the standard antibiotics, streptomycin with the value of $Z i$ that ranged from 10 to $25 \mathrm{~mm}$, therefore making it a potential antibacterial agent of beneficial importance. Similarly, some studies have also reported broad-spectrum activities of EO of $P$. sy/vestris needles [32-34] against multidrug-resistant bacterial strains of $S$. aureus, enterobacterial pathogens [35, 36], and antibiotic-resistant Pseudomonas spp. responsible for freshwater fish diseases (Sekiten-byo) and spoilage [27]. Hence, the EO of $P$. sylvestris needles can serve as an antibacterial agent for the control of multidrug-resistant pathogens and food spoilage bacteria.

The EO inhibited the growth of all the bacteria tested at an appreciable MIC ranging between 0.39 and $1.56 \mathrm{mg} \mathrm{mL}^{-1}$ except for $P$. vulgaris, which also had the lowest $Z i(8 \mathrm{~mm})$. Vyas and Patil [36] obtained similar results with $P$. vulgaris (Zi of $4 \mathrm{~mm}$, the lowest value among all the bacterial isolates tested) when 
the antibacterial activity of EO of $P$. sylvestris was examined against multidrug-resistant enterobacterial pathogens.

This study has validated the antimicrobial potential of EO derived from $P$. sy/vestris. This might be linked to the biologically active constituents available in EO of $P$. sy/vestris needles which enhanced the higher level of antibacterial properties reported against all the tested pathogens in this study. The result obtained from the GC-MS showed that seven antibacterial chemical constituents were present in the EO of $P$. sylvestris. This correlates with the result obtained by some previous researchers who identified seven chemical constituents in the EO of P. sy/vestris [26-28].

Three oxygenated monoterpenes including a-terpineol (the most abundant chemical compound in the study P. sy/vestris), borneol, and fenchol were identified as antibacterial compounds in the P. sy/vestris. Antibacterial effects of oxygenated monoterpenes component of EO of $P$. sylvestris against a wide range of bacterial species, and their useful applications in the production of medicine and cosmetics have been reported [32]. For instance, borneol is one of the traditional Chinese medicine used to treat sore throat, ulcerations, and purulent ear discharge [35]. The presence of these oxygenated monoterpenes in $P$. sylvestris supports its potential as an antimicrobial agent against bacterial pathogens.

Also, hydrocarbon sesquiterpenes (caryophyllene and $\delta$-cadinene) were observed as the antibacterial compound in the EO of $P$. sy/vestris. Interestingly, some scientist in some part of Europe including Estonia, Lithuania and Romania has established the presence of hydrocarbon sesquiterpenes as the major component available in pine oil using GC/MS techniques. Furthermore, the presence of $\beta$ caryophyllene and $\delta$-cadinene apart from hydrocarbon sesquiterpenes constitute the majority of the sesquiterpenes available in the EO of $P$. sylvestris $[15,36,37]$. Several scientists have established that hydrocarbon sesquiterpenes such as $\beta$ - caryophyllene possess other biological properties like antiinflammatory, anticancer, antioxidant, and antifungal properties in addition to their antibacterial activities $[33,38,39]$. It can also inhibit biofilm-forming bacteria implicated in tooth biofilm or plaque in dogs [38], suggesting its application in veterinary medicine. The principal active constituent and antibacterial agent in Schinus molle fruits have been affirmed to possess inhibitory effect against $S$. pneumoniae at MIC of $31.25 \mathrm{mg} \mathrm{mL}^{-1}$. The author further utilized GC/MS to identify the presence of $\delta$-cadinene as the active constitutes responsible for the antibacterial activity against $S$. pneumoniae.

During this study, the presence of oleic acid (monounsaturated fatty acid) and palmitic acid (saturated fatty acids) was also detected in the EO of $P$. sy/vestris. It has been documented that oleic acid portends the capability to inhibits the Fabl enzyme responsible for the fatty acid biosynthesis in bacteria [40], while it could also increase membrane permeability and its leakages, disruption of electron chain transport, and inhibition of the activity of bacterial enzymes [41, 42]. However, oleic acid has been established to exhibit antibacterial activities against Gram-positive clinical and foodborne bacterial pathogens such as Bacillus spp., Micrococcus kristinae, Streptococcus pyogenes, Staphylococcus aureus, and Methicillin-resistant $S$. aureus. Gram-negative bacteria are resistant to unsaturated fatty acids because their outer membrane is highly impermeable to hydrophobic substances $[34,40]$. In another study, it was validated that Gram- 
negative bacteria were only susceptible to short-chain fatty acids ( 6 and below) at high concentrations [43]. The study also reported that Gram positive-bacteria are more susceptible to fatty acid than Gramnegative bacteria, and unsaturated fatty acids like oleic acid have better antibacterial activities than saturated fatty acids like palmitic acid [43].

This study has been able to establish that the presence of oxygenated monoterpenes (a-terpineol, borneol, and fenchol), hydrocarbon sesquiterpenes (caryophyllene and $\delta$-cadinene), and fatty acids (oleic acid and palmitic acids) might be contributing to the antibacterial activities of EO of $P$. sy/vestris. However, future work is to understand the mechanism of action of each antibacterial components of EO of $P$. sylvestris and their synergistic effects on bacterial pathogens.

\section{Conclusion}

This study demonstrated that essential oil P. sylvestris needles from the South Western part of Nigeria have excellent broad-spectrum antibacterial activities, inhibiting the growth of all bacterial isolates tested. The GC/MS analysis revealed the presence of compounds including a-terpineol, borneol, fenchol, palmitic acid, caryophyllene, oleic acid, and $\delta$-cadinene, which may be contributing to the antibacterial activities of $P$. sylvestris EO. The P. sylvestris needles EO and its components is a promising antibacterial agent that can be explored on a commercial scale as a potential source of antibacterial compounds for the control of pathogens, most especially bacterial species tested in this study.

\section{Declarations}

\section{Acknowledgement}

We acknowledge the support of the laboratory technologists of the Departments of Microbiology and Pure \& Applied Chemistry, Osun State University for their support during the Laboratory analysis.

\section{Declaration of interests}

The authors declare that they have no known competing financial interests or personal relationships that could have appeared to influence the work reported in this paper.

\section{References}

1. Ventola CL (2015) The antibiotic resistance crisis: part 1: causes and threats. P T 40(4):277-283. PMID: 25859123; PMCID: PMC4378521

2. Economou V, Gousia P (2015) Agriculture and food animals as a source of antimicrobial-resistant bacteria. Infect Drug Resist 8:49-61 
3. Levy SB, Marshall B (2004) Antibacterial resistance worldwide: causes, challenges and responses. Nat Med 10(12):122-129

4. Fokunang CN, Ndikum V, Tabi OY, Jiofack RB, Ngameni B, Guedje NM, Tembe-Fokunang EA, Tomkins P, Barkwan S, Kechia F, Asongalem E (2011) Traditional medicine: past, present and future research and development prospects and integration in the National Health System of Cameroon. Afr $\mathrm{J}$ of Tradt Complement Altern Med 8(3):284-295

5. Gogoi R, Loying R, Sarma N, Begum T, Pandey SK, Lal M (2020) Comparative Analysis of In-Vitro Biological Activities of Methyl Eugenol Rich Cymbopogon khasianus Hack., Leaf Essential Oil with Pure Methyl Eugenol Compound. Curr Pharm Biotechnol 21(10):927-938

6. Veeresham C (2012) Natural products derived from plants as a source of drugs. J Adv Pharm Tech Res 3(4):200

7. Feyaerts $A F$, Luyten $W$, Van Dijck $P$ (2020) Striking essential oil: tapping into a largely unexplored source for drug discovery. Sci Rep 10(1):1-11

8. Kalemba D, Kunicka A (2003) Antibacterial and antifungal properties of essential oils. Curr Med Chem 10(10):813-829

9. Zhang Y, Xin C, Cheng C, Wang Z (2020) Antitumor activity of nanoemulsion based on essential oil of Pinus koraiensis pinecones in MGC-803 tumor-bearing nude mice. Arabian Journal of Chemistry (2020) 13, 8226-8238

10. Vostinaru O, Heghes SC, Filip L (2020) Safety Profile of Essential Oils. In Essential Oils-Bioactive Compounds, New Perspectives and Applications. IntechOpen

11. Hong EJ, Na KJ, Choi IG, Choi KC, Jeung EB (2004) Antibacterial and antifungal effects of essential oils from coniferous trees. Biol Pharm Bull 27(6):863-866

12. Anupama G, Netravathi, Das KK, Avinash M (2019) Essential oils: A novel source for food preservation. Journal of Pharmacognosy Phytochemistry 8(1):2098-2101

13. Munda S, Dutta S, Pandey SK, Sarma S, Lal M (2019) Antimicrobial activity of essential oil of medicinal and aromatic plants of Northeast India: A Biodiversity hotspot. J Essent Oil-Bearing Plants 22(1):105-119

14. Paw M, Gogoi R, Sarma N, Pandey SK, Borah A, Begum T, Lal M (2020) Study of Anti-oxidant, Antiinflammatory, Genotoxicity, and Antimicrobial Activities and Analysis of Different Constituents found in Rhizome Essential Oil of Curcuma caesia Roxb., Collected from North East India. Curr Pharm Biotechnol 21(5):403-413

15. de Araújo ACJ, Freitas PR, dos Santos Barbosa CR, Muniz DF, Rocha JE, da Silva ACA, de Morais Oliveira-Tintino CD, Ribeiro-Filho J, da Silva LE, Confortin C and do Amaral W (2020) GC-MS-FID characterization and antibacterial activity of the Mikania cordifolia essential oil and limonene against MDR strains. Food Chem. Toxicol. 136: 111023

16. Hassan A, Amjid I (2009) Gas chromatography-mass spectrometric studies of essential oil of Pinus roxburghaii stems and their antibacterial and antifungal activities. Journal of Medicinal Plants Research 3(9):670-673 
17. Mazari K, Bendimerad N, Bekhechi C, Fernandez X (2010) Chemical composition and antimicrobial activity of essential oils isolated from Algerian Juniperus phoenicea L. and Cupressus sempervirens L. Journal of Medicinal Plants Research 4:959-964

18. Namshir J, Shatar A, Khandaa O, Tserennadmid R, Shiretorova VG, Nguyen MC (2020) Antimicrobial, antioxidant and cytotoxic activity on human breast cancer cells of essential oil from Pinus sy/vestris. var mongolica needle. Mong J Chem 21(47):19-26

19. Garzoli S, Masci VL, Caradonna V, Tiezzi A, Giacomello P, Ovidi E (2021) Liquid and Vapor Phase of Four Conifer-Derived Essential Oils: Comparison of Chemical Compositions and Antimicrobial and Antioxidant Properties. Pharmaceuticals 14:134. https://doi.org/10.3390/ph14020134

20. Adjaoud A, Laouer H, Braca A, Cioni P, Moussi K, Berboucha-Rahmani M, Abbaci H, Falconieri D (2020) Chemical composition, antioxidant and insecticidal activities of a new essential oil chemotype of Pinus nigra ssp. mauritanica (Pinaceae), northern Algeria, Plant Biosystems - An International Journal Dealing with all Aspects of Plant Biology, DOI:

10.1080/11263504.2020.1857871

21. Vek V, Poljanšek I, Humar M, Willför S, Oven P (2020) In vitro inhibition of extractives from knotwood of Scots pine (Pinus sylvestris) and black pine (Pinus nigra) on growth of Schizophyllum commune, Trametes versicolor, Gloeophyllum trabeum and Fibroporia vaillantii. Wood Science and Technology (2020) 54:1645-1662. https://doi.org/10.1007/s00226-020-01229-7

22. Sonibare 00 , Olakunle $K$ (2008) Chemical composition and antibacterial activity of the essential oil of Pinus caribaea from Nigeria. Afr J Biotech 7(14):2462-2464. DOI:10.5897/AJB08.37

23. Zafar I, Fatima A, Khan SJ, Rehman M, Mehmud S (2010) GC-MS studies of needles essential oils of Pinus roxburghaii and their antimicrobial activity from Pakistan. Electronic Journal of Environmental Agricultural Food Chemistry 9(3):468-473

24. Maciąg A, Milaković D, Christensen HH, Antolović V, Kalemba D (2007) Essential oil composition and plant-insect relations in Scots pine (Pinus sy/vestris L.). Food Chemistry Biotechnology 71:71-95

25. Bergström B (2003) Chemical and structural changes during heartwood formation in Pinus sylvestris. Forestry 76(1):45-53

26. Silori GK, Kushwaha N, Kumar V (2019) Essential Oils from Pines: Chemistry and Applications. In: Malik S (ed) Essential Oil Research, Trends in Biosynthesis, Analytics, Industrial Applications and Biotechnological Production. Springer, Cham. DOI:10.1007/978-3-030-16546-8_10

27. Fayemiwo KA, Adeleke MA, Okoro OP, Awojide SH, Awoniyi IO (2014) Larvicidal efficacies and chemical composition of essential oils of Pinus sy/vestris and Syzygium aromaticum against mosquitoes. Asian Pac J Trop Biomed 4(1):30-34

28. Kamaityte-Bukelskiene L, Ložiene K, Labokas J (2021) Dynamics of Isomeric and Enantiomeric Fractions of Pinene in Essential Oil of Picea abies Annual Needles during Growing Season. Molecules 26:2138. https://doi.org/10.3390/molecules26082138

29. Elyemni M, Louaste B, Nechad I, Elkamli T, Bouia A, Taleb M, Chaouch M, Eloutassi N (2019) Extraction of essential oils of Rosmarinus officinalis L. by two different methods: Hydrodistillation 
and microwave assisted hydrodistillation. Sci. World J. 2019: 6

30. Adams RP (2007) Identification of essential oil components by gas chromatography/ mass spectrometry, 4th Edition. Allured Publ., Carol Stream, IL

31. Akinpelu BA, Igbeneghu OA, Awotunde Al, Iwalewa EO, Oyedapo $O 0$ (2014) Antioxidant and antibacterial activities of saponin fractions of Erythropheleum suaveolens (Guill. and Perri.) stem bark extract. Sci Res Essays 9(18):826-833

32. Keeratirathawat S, Nair J, Levitan J (2013) The antibacterial efficacy of pine oils on pathogens commonly found in biosolids applied to pine plantations. Int J Environ Waste Manag 12(2):146-153

33. Kačániová M, Gasper J, Terentjeva M, Kunová S, Kluz M, Hanus P, Puchalski C (2018) Antimicrobial Activity and Resistance of Microorganisms Isolated from Honey Bees. Scientific Papers: Animal Science Biotechnologies 51(1):133-138

34. Kurti F, Giorgi A, Beretta G, Mustafa B, Gelmini F, Testa C, Angioletti S, Giupponi L, Zilio E, Pentimalli D, Hajdari A (2019) Chemical composition, antioxidant and antimicrobial activities of essential oils of different Pinus species from Kosovo. J Essent Oil Res 31(4):263-275

35. Mitić ZS, Jovanović B, Jovanović S, Mihajilov-Krstev T, Stojanović-Radić ZZ, Cvetković VJ, Mitrović TL, Marin PD, Zlatković BK, Stojanović GS (2018) Comparative study of the essential oils of four Pinus species: Chemical composition, antimicrobial and insect larvicidal activity. Ind Crops Prod 111:55-62

36. Vyas P, Patil S (2011) Antimicrobial activity of essential oils against multidrug resistant enterobacterial pathogens. Trends in Biosciences 4(1):23-24

37. Kotan R, Kordali S, Cakir A (2007) Screening of antibacterial activities of twenty-one oxygenated monoterpenes. Z Naturforsch C J Biosci. 62(7-8): 507 - 13. doi: 10.1515/znc-2007-7-808. PMID: 17913064

38. Francomano F, Caruso A, Barbarossa A, Fazio A, La Torre C, Ceramella J, Mallamaci R, Saturnino C, lacopetta D, Sinicropi MS (2019) $\beta$-Caryophyllene: A Sesquiterpene with Countless Biological Properties. Appl Sci 9(24):5420

39. Dilika F, Bremner PD, Meyer JJM (2000) Antibacterial activity of linoleic and oleic acids isolated from Helichrysum pedunculatum: a plant used during circumcision rites. Fitoterapia 71(4):450-452

40. Cheng C, Liu XW, Du FF, Li MJ, Xu F, Wang FQ, Liu Y, Li C, Sun Y (2013) Sensitive assay for measurement of volatile borneol, isoborneol, and the metabolite camphor in rat pharmacokinetic study of Borneolum (Bingpian) and Borneolum syntheticum (synthetic Bingpian). Acta Pharmacol $\operatorname{Sin} 34(10): 1337-1348$

41. Orav A, Kailas T, Liiv M (1996) Analysis of terpenoic composition of conifer needle oils by steam distillation/extraction, gas chromatography and gas chromatography-mass spectrometry. Chromatographia 43:215-219

42. Venskutonis PR, Vyskupaityte K, Plausinaitis R (2000) Composition of essential oils of Pinus sy/vestris L. from different locations of Lithuania. J Essent Oil Res 12(5):559-565 
43. McGaw LJ, Jäger AK, Van Staden J (2002) Antibacterial effects of fatty acids and related compounds from plants. S Afr J Bot 68(4):417-423

44. Khan M, Al-Saleem MSM, Alkhathlan HZ (2016) A detailed study on chemical characterization of essential oil components of two Plectranthus species grown in Saudi Arabia. Journal of Saudi Chemical Society 20(6):711-721

45. Chung TY, Eiserich JP, Shibamoto T (1993) Volatile compounds isolated from edible Korean chamchwi (Aster scaber Thunb). J Agric Food Chem 41:1693-1697

46. Jordan MJ, Margaria CA, Shaw PE, Goodner KL (2002) Aroma active components in aqueous Kiwi fruit essence and Kiwi fruit puree by GC-MS and multidimensional GC/GC-O. J Agric Food Chem 50:5386-5390

47. Pino JA, Mesa J, Munoz Y, Marti MP, Marbot R (2005) Volatile components from mango (Mangifera indica L.) cultivars. J Agric Food Chem 53:2213-2223

48. Leffingwell JC, Alford ED (2005) Volatile constituents of perique tobacco. Electronic Journal of Environmental Agricultural Food Chemistry 4(2):899-915

\section{Tables}

Due to technical limitations, table 1 is only available as a download in the Supplemental Files section.

\section{Figures}


- Undiluted oils of $P$. sylvestris

- Streptomycin

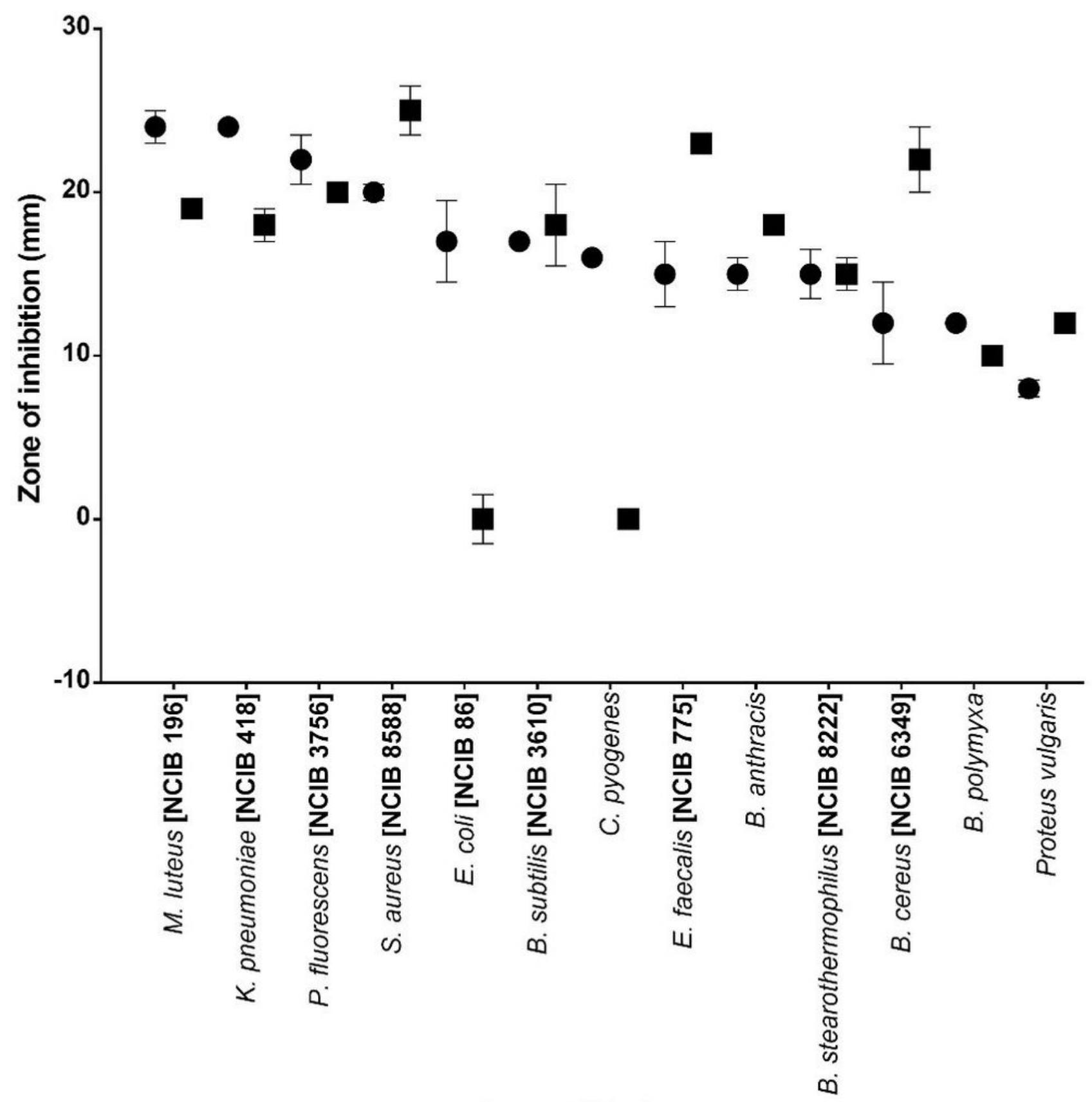

Bacterial Isolates

\section{Figure 1}

Antibacterial activity of essential oil P. sylvestris against thirteen bacterial isolates with diameter of zone of inhibition $(\mathrm{mm})$ 


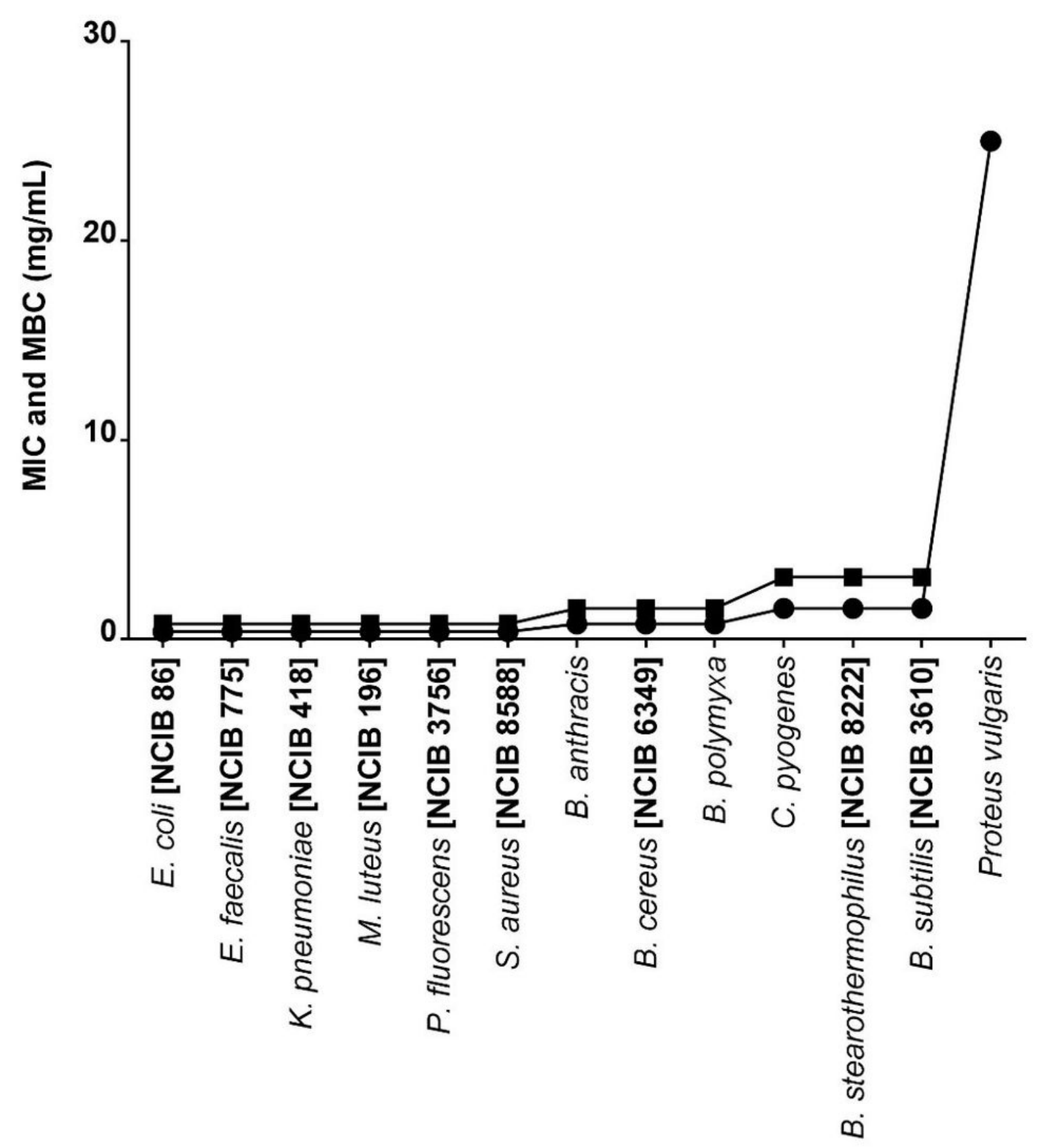

\section{Bacterial Isolates}

Figure 2

The minimum inhibitory and bactericidal concentration of essential oil of P. sylvestris against tested bacterial isolates

\section{Supplementary Files}

This is a list of supplementary files associated with this preprint. Click to download. 
- SpringerMCRTable.docx

- SpringerMCRSuppl.docx 